\title{
MISCELLANEOUS.
}

\section{Salmo cambricus.}

\section{To the Editors of the Annals and Magazine of Natural History.}

Gentlemen,-I find that the name of Salmo cambricus, which I have given to the Charr of Llanberris Lake, has been previously used by Donovan for the Sewin of Wales. Therefore, to prevent confusion, I propose to change the name of the former species into Salmo Perisii.

I remain, Gentlemen,

Your obedient Servant,

British Museum, Nov. 28, 1864.

A. GÜnther.

\section{On the Cetacea of the French Mediterranean Coasts. \\ By M. Paul Gervais.}

After some remarks on the necessity of studying the osteological characters in discriminating the species of Cetaceans, M. Gervais states that he has been able to ascertain the existence on the French coasts of the Mediterranean of nine species of those animals, belonging to nearly as many genera. Upon these species he makes the following observations :-

1. The Cachalot (Physeter macrocephalus).-This species is very rare, the occasional reported occurrence of individuals generally referring to large species of Delphinidæ. A true Cachalot was taken in 1856, by the fishermen of Saint Nazaire; and a considerable portion of its lower jaw is preserved in the collection of the Marist Fathers, at La Seyne, near Toulon.

2. The Ziphius (Ziphius cavirostris, Cuv.).-This species, long: regarded as fossil, really exists in the Mediterranean; the specimen of which the skull was described by Cuvier (Rech. Ossem. foss.) was found by the fishermen of the Gulf of Bouc. Others have since been obtained, and each of them has been described as a new speciesDelphinus Desmarestii, Risso (taken at Nice), D. Philippii, Cocco (Straits of Messina), Hyperoodon Doumetii, Gray (Corsica), and $\boldsymbol{H}$. Gervaisii, Duvernoy (Aresquiès).

3. The Grampus (Orca gladiator).-This species has only twice been captured. One was taken about twenty-five years ago at Cette; its dental formula was $\frac{11}{12}$. Another came ashore at Elne (Pyrénées orientales) in 1857; but its lower jaw (the only fragment preserved) contains only ten teeth, so that M. Gervais does not feel sure of its being of the same species as the Cette specimen. It is also impossible to say whether it may be identical with the Delphinus Feres.

4. The Round-headed Porpoise (Globiceps). -The names Delphinus melas, D. deductor, and D. globiceps have been given to a large oceanic species, the type of the genus Globiceps of Gray. Similar species, if not mere varieties, have been brought from the south coast of the United States, from Guadaloupe, New Zealand, and the Japanese seas. 
But it is doubtful whether this species exists in the Mediterranean. The genus Globiceps has been recognized by M. Gervais in some Delphinidæ of 14-17 feet long, of which a shoal of about fifteen ran on shore in the neighbourhood of Barcarès (Pyrénées orientales) in February 1864. Four of these specimens reached M. Gervais, and he compared the skeleton of one of them with different skeletons of G. melas in the Museum of Paris. The only differences that can be pointed out reside in the curvature of the incisive bones, and in the somewhat more obtuse appearance of the teeth; but equivalent differences also occur between the specimens of Globiceps from other seas when carefully compared, so as, to a certain extent, to justify the supposed species which have been admitted in this genus by authors. The Mediterranean Globiceps thus appears to constitute a new race, if not a new species. Like the Cetacea of this genus which live in the ocean, it has the head much inflated, and the muzzle short; and its colour is black, except beneath, where it presents a large median band commencing in the form of a heart near the throat, and extending to the anus.

5. Risso's Porpoise (Grampus Rissoanus).-G. Cuvier has described this species, which is very nearly allied to his Delphinus griseus; but the former lives in the Mediterranean, the latter on the coasts of Brittany. The cranium of this species presents characters which are easily recognized. The Museum of Paris possesses two skulls from specimens taken at Nice by Risso and Laurillard; there is another in the Museum of Marseilles obtained from one of a shoal which came into Carry (Bouches-du-Rhône) two years ago.

6. The Bottle-nosed Dolphin (Tursiops Tursio).-This is not so rare as the preceding species, but far less common than the Delphinus Delphis. M. Gervais has specimens taken in the Gulf of Lyons, especially at Cette and La Nouvelle and at Gruissau.

7. The Common Dolphin (Delphinus Delphis).-This is the stationary Dolphin of the coasts. One of its chief distinctive marks consists in the widened double groove on the face of its palate. This double groove is visible after the removal of the membrane of the palate; it does not exist in the D. Tethyos of Gervais.

8. Dolphin of Tethys (Delphinus Tethyos).-Of this the author knows only two individuals - one taken at the mouth of the Orb (Hérault) in 1852, the other in the vicinity of Port-Vendres (Pyrénées orientales), of which the skull is in the collection of Dr. Pinchinat.

9. The Rorqual (Rorqualus antiquorum).-This great Cetacean exhibits the same characters in the Mediterranean as in the ocean; it is the Mysticetos of Aristotle. It is seen from time to time on the French coasts, especially those of the Pyrénées orientales and the Var. In 1862 a female, with her young, remained for more than a month chiefly in the small bay of Paulilles, Port-Vendres, and Collioure. This was perhaps the Cetacean which, some months later, ran on shore at the rocks of Borro, on the Spanish coast, and was towed to Llanza, where M. Gervais saw it.

Such Cetaceans rarely run aground on the sandy shores of Lan- 
guedoc and La Camargue; but the great whale with a channelled belly, mentioned by Daléchamp as having come ashore in his time near Montpellier, must be regarded as a Rorqual, and the jaws of this species preserved at Frontignan have probably a similar origin.

M. Gervais records, as specimens which have grounded during more recent periods, one, 17 feet long, of which the skeleton is in the museum of Perpignan; a larger one, taken at Saint-Cyprien, described by Farines and Carcassonne as Balcenoptera aragous; that of Saint-Tropez in 1833; those of the île Sainte-Marguerite, one in 1797, described by Lacépède and Cuvier, the other in 1864; and two or three others taken near Toulon, of which the skulls or entire skeletons have been preserved.-Comptes Rendus, Nov. 28, 1864, p. 876 .

\section{Descriptions of some new Fishes. By Prof. Kner.}

The fishes described by Professor Kner were collected by Dr. E. Gräffe on the private expeditions fitted out by MM. J. C. Godeffroy \& Son, of Hamburg.

\section{Family Labroidæ.}

Thysanocheilus, nov. gen.

Char. gen. Ambo labia margine fimbriato, dentes acuti uniseriales supra et infra, in medio ossis intermaxillaris 4, inframaxillaris 2 dentes canini, 2 quoque supra ad oris angulum; totum caput, labiis exceptis, squamis minutis tectum, nec non guttur penitus clausum ad isthmum usque; trunci squamæ magnæ; linea lateralis continua, simplex; pinnæ ventrales in filum prolongatæ, caudalis rotundata.

\section{Thysanocheilus ornatus.}

T. color universalis nigrescens, ad abdominis latera albicans; truncus et fere omnes pinnæ lineis et punctis cyaneis obsitæ. D. 7/12. A. $3 / 10$. Sq. long. 28 , vertic. $15-16$.

From Upolu (Navigator's or Samoa Islands). Catal. no. 791. Most nearly allied to Labrichthys cyanotania, Bleek. (Atlas, i.tab. 22. fig. 1); but in this the lower lip only is fringed, and there is only one canine in the upper jaw, at the angle of the mouth; it also wants the complete union and scaling of the sides of the throat; and the colour and form of the head differ. 


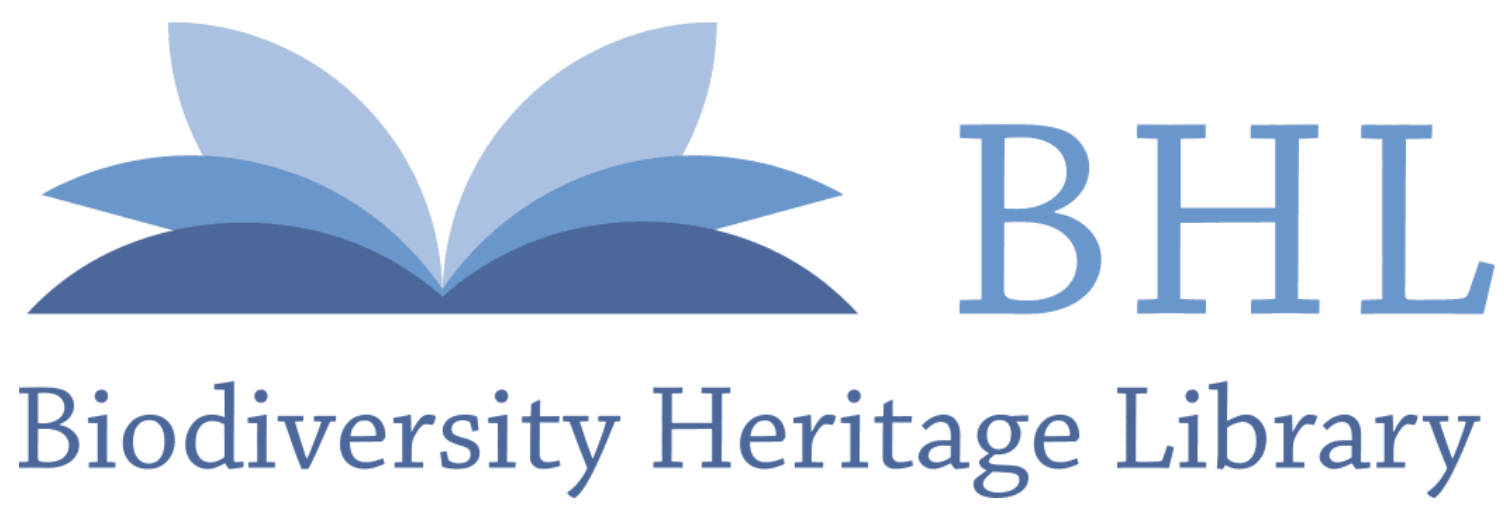

Gervais, Paul. 1865. "On the Cetacea of the French Mediterranean coasts." The Annals and magazine of natural history; zoology, botany, and geology 15, 75-77.

View This Item Online: https://www.biodiversitylibrary.org/item/72310

Permalink: https://www.biodiversitylibrary.org/partpdf/61544

\section{Holding Institution}

University of Toronto - Gerstein Science Information Centre

\section{Sponsored by}

University of Toronto

\section{Copyright \& Reuse}

Copyright Status: NOT_IN_COPYRIGHT

This document was created from content at the Biodiversity Heritage Library, the world's largest open access digital library for biodiversity literature and archives. Visit BHL at https://www.biodiversitylibrary.org. 